\title{
Outlays on Fixed Assets for Environmental Protection in Dolnośląskie Voivodeship - Selected Problems
}

\author{
Joanna SZYMAŃSKA ${ }^{1}$, Pavel JEDLIČKA ${ }^{2}$ \\ ${ }^{1}$ Wrocław University of Economics, Wrocław, Poland \\ joanna.szymanska@ue.wroc.pl \\ ${ }^{2}$ University of Hradec Králové, Hradec Králové, Czech Republic \\ pavel.jedlicka@uhk.cz
}

\begin{abstract}
This article presents the value of fixed investment, which should serve the development of environmental protection in the Dolnośląskie Voivodeship in the years 2011-2015. Particular attention was paid in this study on the analysis of the structure of distribution expenses by directions of investing. This article also focuses attention on the sources of financing investments of environmental protection. This paper presents the positive changes that have occurred in the technical infrastructure related to environmental protection in the Dolnośląskie Voivodeship in the years 20112015.
\end{abstract}

Keywords: Outlays on Fixed Assets, Environmental Protection, Dolnośląskie Voivodeship.

\section{Introduction}

Natural habitats are all ecological (abiotic and biotic) factors that are directly related to the life and development of the organism of the species or its population. Industrialization and urbanization of the areas in question cause deformation of the original natural environment. There appears an anthropogenic environment, whose creator, with the participation of nature, is a man.

Environmental protection processes have developed particularly intensively in the second half of the twentieth century. While initially their main goal was to create conditions for maintaining high ecosystem use, it is now essential to preserve biodiversity on the planet as a prerequisite for the continued existence and development of humanity and to protect against radical changes in the climate $[1,3$, $5]$.

Outlays on fixed assets used for environmental protection form part of the investment outlays (financial or tangible), the remaining part of which constitutes expenditures on the so-called first investment equipment and other costs related to the realization of investments which do not increase the value of fixed assets). These include expenditures on: acquisition of land (including perpetual usufruct of land), buildings, premises and civil and water engineering facilities (including, for example, construction and assembly works, design and cost estimate documentation) means of 
transport, tools, instruments, movables and equipment, and other fixed assets designed to achieve environmental effects [6].

The concept of fixed assets is to be understood as both new and existing goods, purchased, manufactured on their own and purchased through a financial lease with a useful life of more than one year, as well as any additions, changes, improvements and renewals that prolong their useful life or increase their productivity. fixed assets [6].

Expenditures on fixed assets that serve the protection of the environment in specific regions, regions or the whole of the country include expenditures for the following groups of undertakings: waste water management and protection, air and climate protection, waste management, biodiversity and landscape protection, noise reduction and vibration, other funding directions $[1,4,6]$.

The aim of the study is to analyze the structure of expenditures on fixed assets for environmental protection in Dolnośląskie, due to the directions of investment and sources of financing and the presentation of selected material effects in the examined area. The time horizon of the study was years 2011-2015.

\section{Methods and sources of data}

The study was based on the analysis of data using universal statistics. For the preparation of the article, selected items from the literature of the subject, specialized studies and data of universal statistics, which are included in the yearbooks Environmental protection.

\section{Structure of expenditure on fixed assets for environmental protection}

Dolnośląskie Voivodship adopted for analysis is industrial-agricultural. They decide:

- historical conditions (development, especially since the nineteenth century, of the Sudeten Industrial District based on diverse and abundant mineral resources, mainly hard coal and rock raw materials and a large-scale industrial center in Wrocław, and then in Legnica and other former German cities in Lower Silesia);

- processes of intensive industrialization and urbanization of parts of the Lower Silesian Voivodeship in the seventies of the twentieth century (commencement of the processing of copper ores on the basis of newly discovered, very rich deposits of these ores, further development of the Wałbrzych Coal Basin, development of the Wroclaw Industrial District, creation and development of the Turoszów Industrial District, lignite resources and the launch of the Turoszów power plant);

- Poland's accession to the European Union (new industrial investments, service trade and housing development related to foreign capital inflows and the strengthening of domestic capital). 
As emphasized by B. Poskrobko and T. Poskrobko, the management of the natural environment is the subject of management as well as entities affected by management tools (individuals, groups and communities, business entities and various organizational units) [5].

Share of expenditures on environmental protection, in total expenditure on fixed assets serving both water management and environmental protection in the Dolnośląskie voivodeship was - during the period considered (in the years 2011-2015) - average $63.7 \%$ (compared with $36.3 \%$ share of fixed assets for water management). A significantly greater share of the analyzed environmental outlays, compared to the corresponding share of expenditure on water management, was due to the established priorities for environmental protection (European Union), in line with the adopted socioeconomic needs (national, regional and local) and financial investor.

In the analyzed period (in the years 2011-2015), fixed capital expenditures, which should serve to improve the situation in the protection of the environment in the Dolnośląskie Voivodeship showed some variations: fall-height (Figure 1). This should in particular be linked to the depletion of resources available to the end of some EU programs (a decrease in expenditure in the years 2011-2013) and a new support period (growth in the years 2014-2015). The observed increase in the analyzed expenditures was due both to the existing needs in terms of improvement of the environmental situation as well as to the financial capacity of the investors. Supporting the construction, extension or modernization of the technical infrastructure serving the protection of the environment, especially the improvement of the sanitary condition of rural areas in Poland, was adopted - after the accession of Poland to the European Union - as one of the priorities of sustainable development [8].

The increase in expenditures on fixed assets, which should be used to protect the environment in the Dolnośląskie Voivodeship (in comparison with year 2011), was accompanied by an increase in per capita expenditure. This ratio increased to PLN 403 in the year 2015 (by half compared to the year 2011). It also increased on average in Poland, to 394 PLN per capita in 2015 (respectively by a quarter, less dynamically than in the analyzed voivodeship (see Fig. 1).

In the analysed period (in the years 2011-2015) the total number of inhabitants of the Lower Silesian Voivodeship decreased by 12370 people. The phenomenon was affected by the decrease in the number of inhabitants of cities (by 25705 people), as the number of inhabitants of the village increased by 13335 people. 


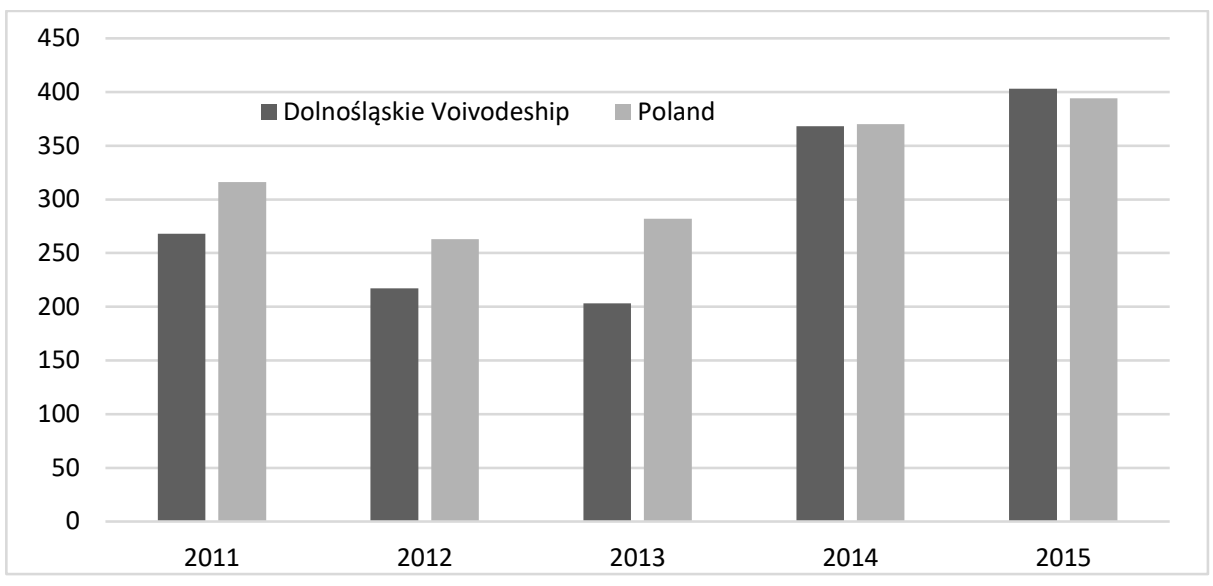

Fig. 1. Outlays on fixed assets for environmental protection in the voivodeship and on average in Poland in the years 2011-2015 (PLN per capita) [5].

In general expenditure on fixed assets should serve the protection of the environment in the province. The investments in sewage management and water protection $(54 \%)$ were the highest average yearly shares (years 2011-2015). In the first three cases, there were also investments in: air and climate protection $(32.5 \%)$ and waste management, but with a significantly lower share $(7.5 \%)$. The remaining sites were ranked according to the decreasing share: the remaining investment directions included $4.5 \%$ of total expenditure, noise and vibration reduction $(1.2 \%)$ and biodiversity protection ( $0.3 \%$ ) (see Fig. 2 ).

The identified structure of the expenditures analysed is closely related to the existing needs of improving the quality of life of the inhabitants of these areas and adopted by Poland after the accession to the European Union, the objectives of regional development [8].

By giving a detailed analysis of the structure of expenditures for fixed assets for environmental protection in the Dolnośląskie Voivodeship, in the years 2011-2015, some changes may be observed according to the directions of investment. While in the years 2011-2013 most of the total of the expenditure under consideration was allocated to sewage management and water protection, the latter is allocated to air and climate protection in the later period (in the years 2014-2015).

Atmospheric air is one of the most important protected components of the natural environment, as emphasized in the literature of the subject. Due to international agreements, the protection of atmospheric air also includes the ozone layer and the climate [2]. 


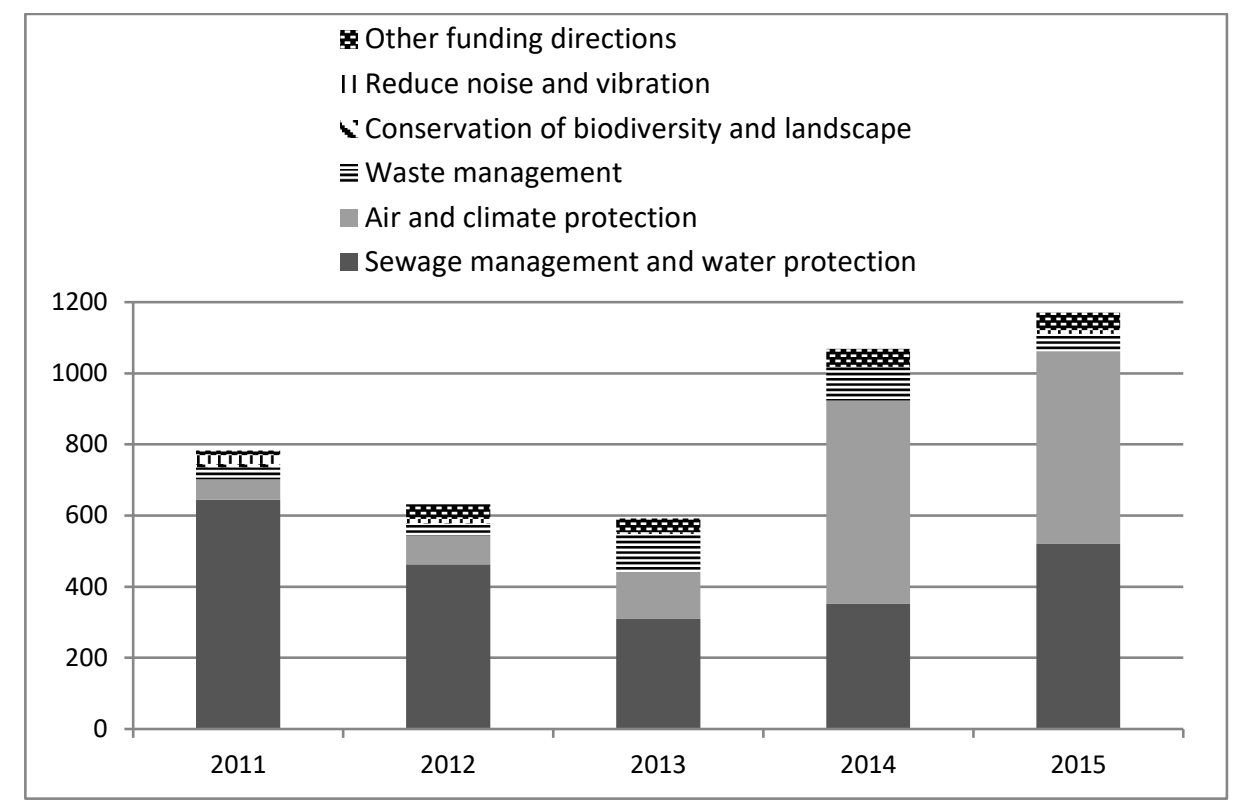

Fig. 2. Outlays on fixed assets for the protection of the environment in the Province Dolnośląskie in the years 2011-2015 according to major directions of investment (mln PLN, current prices) [6].

Financing of fixed assets for environmental protection may come from the own resources of investors, from budgets: central, county, commune, from foreign sources, from ecological funds and from other sources. Most of these types of investments are funded financially from mixed sources.

The largest average annual share in expenditures for fixed assets is for environmental protection in the voivodeship. According to the sources of financing, in the audited period (years 2011-2015), they had own funds (56.1\% - from the own funds of the enterprises and from the own funds of the communes). In the second place, but with a significantly smaller share, the funds from the ecological funds $(17.6 \%)$ and the third ones $(15.9 \%)$ came from abroad. The following places were ranked according to the decreasing share: domestic loans $(8.2 \%)$, other funds $(0.9 \%)$, central budget funds $(0.6 \%)$, municipal budget funds $(0.3 \%)$, funds from the budget of the voivodeship and from the country budget $(0.2 \%$ each) (see Fig. 3 ).

By providing a detailed analysis of the structure of outlays for the construction, extension or modernization of the collective water and sewerage network, it is noted that the majority of these expenditures were allocated to municipalities. They also increased their share of EU structural funds. In the case of the development of collective sewer, the share of expenditures from other sources (eg by the Agricultural Property Agency, District Water Supply and Sewerage Enterprise, EcoFund, Regional Water Management Board) increased. The construction, expansion or modernization of collective sewage treatment plants was the most supported by the expenditures 
from the environmental protection and water management funds, then from the European Union structural funds and allocated by the local governments [6].

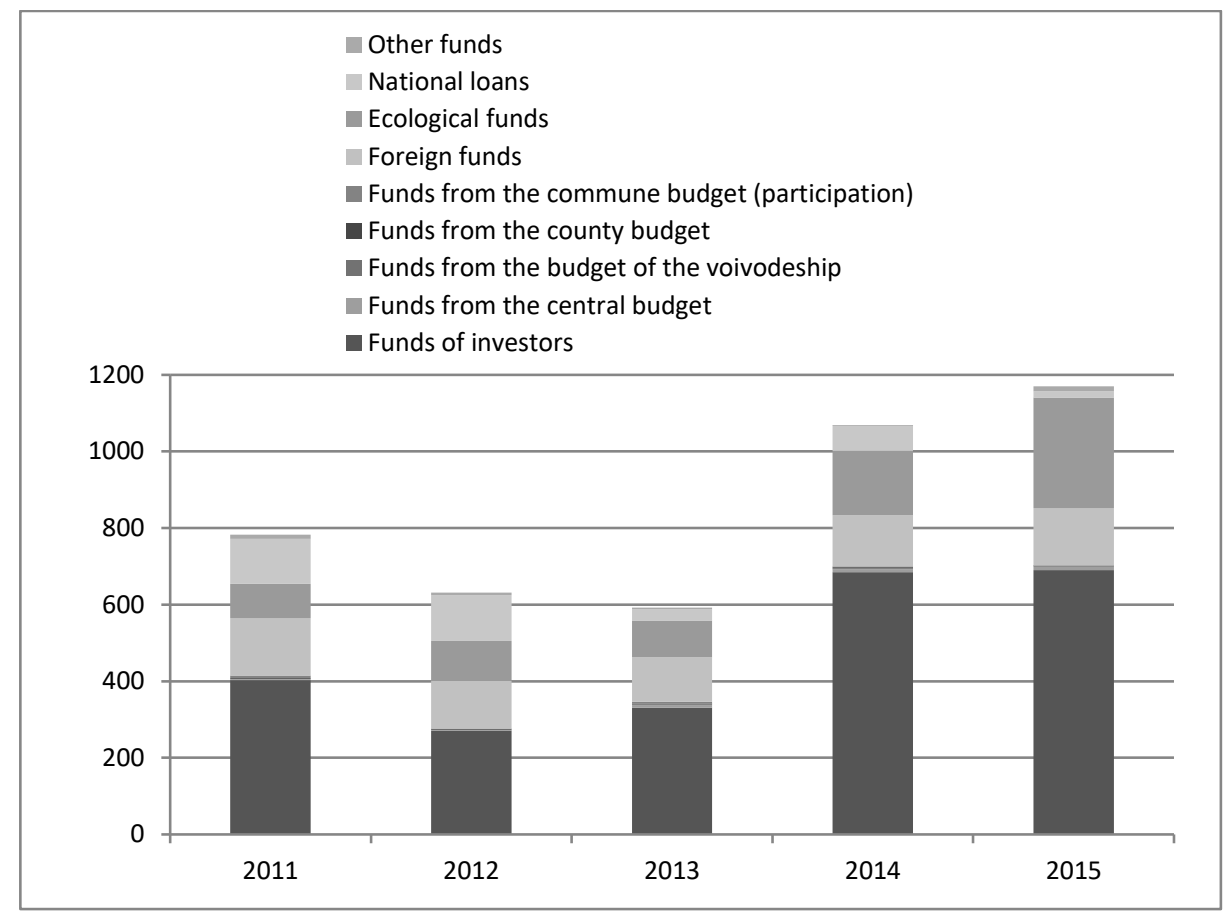

Fig. 3. Outlays on fixed assets for the protection of the environment in the Dolnoślaskie voivodship in the years 2011-2015 according to sources of financing (mln PLN, current prices) [6].

As emphasized in the literature of the subject, ecological funds in Poland (the National Fund for Environmental Protection and Water Management, provincial, district and municipal funds, the Agricultural Land Protection Fund, the Forest Fund) are a specific source of funding for conservation initiatives and water management.

They are involved in acquiring and redistributing financial resources for the implementation of priority environmental projects. Funds for environmental protection projects include the Cohesion Fund and the Structural Funds (European Regional Development Fund, European Social Fund, European Agricultural Guidance and Guarantee Fund). Financial resources from the Operational Program Infrastructure and Environment, the European Regional Development Fund, the Norwegian Financial Mechanism and the European Economic Area Financial Mechanism, and the Financial Instrument LIFE+ [5]. 


\section{$4 \quad$ Examples of tangible effects of investment in environmental protection}

As a result of the increase in expenditure on fixed assets used to protect the environment in Dolnośląskie Voivodeship in the years 2011-2015 certain tangible effects were obtained (Fig. 4-7).

Additional sections of the sewerage network (and water supply) were added to use, which contributed to the maintenance of the length of these networks on the trend path. In the year 2015 the length of the sewerage network was in the voivodeship $10914.9 \mathrm{~km}$ (increase by $1 / 4$ compared to 2011), water supply was longer (by law $4800 \mathrm{~km}$ ). In this drawing (see Fig. 3) the predicted trend lines are also shown (predicted linear trend line of length of the water supply network (T-1) and predicted linear trend line of length of sewerage network (T-2) (see Fig. 4).

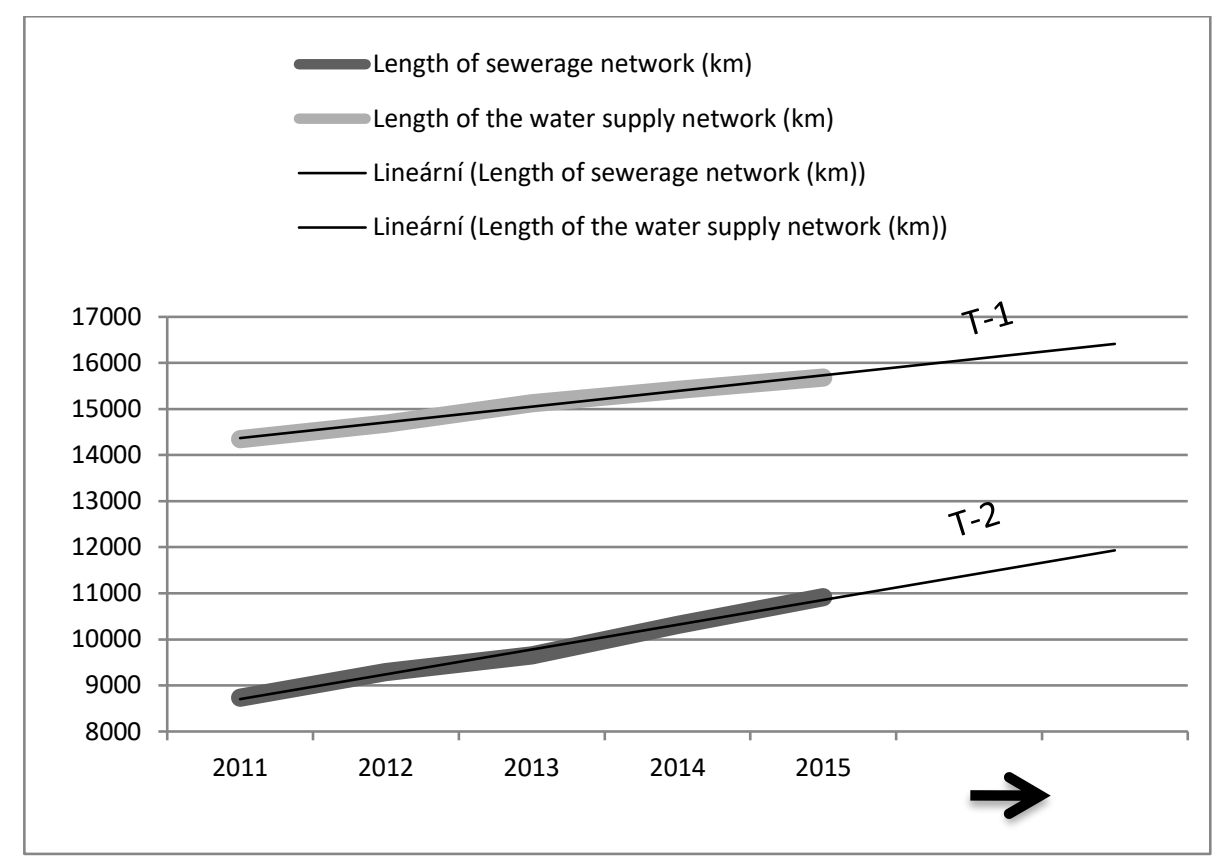

Fig. 4. Length of the water and sewage network in the Dolnośląskie voivodeship in years 20112015 and forecasted linear trend lines $(\mathrm{km})[7]$.

The number of sewage connections leading to residential buildings has increased, to 221660 total connections in the Dolnośląskie voivodeship in year 2015 (an increase of $22 \%$ compared to year 2011). In the rural areas of Dolnośląskie voivodeship their growth has been more dynamic (38\% growth, up to 86795 in year 2015). The number of connections to the water supply system was still higher than the number of sewage connections, both in the Dolnośląskie voivodeship (343513 connections to the water supply system against 221660 connections to the sewerage network in year 2015) and 
in the rural areas of Dolnośląskie voivodeship (188861 connections to the water supply system against 86795 connections to the sewerage network). However, relations have been improved: the number of sewage connections leading to residential buildings to the number of analogue water connections. While in year 2011 the total number of water supply connections in the Dolnośląskie voivodeship was

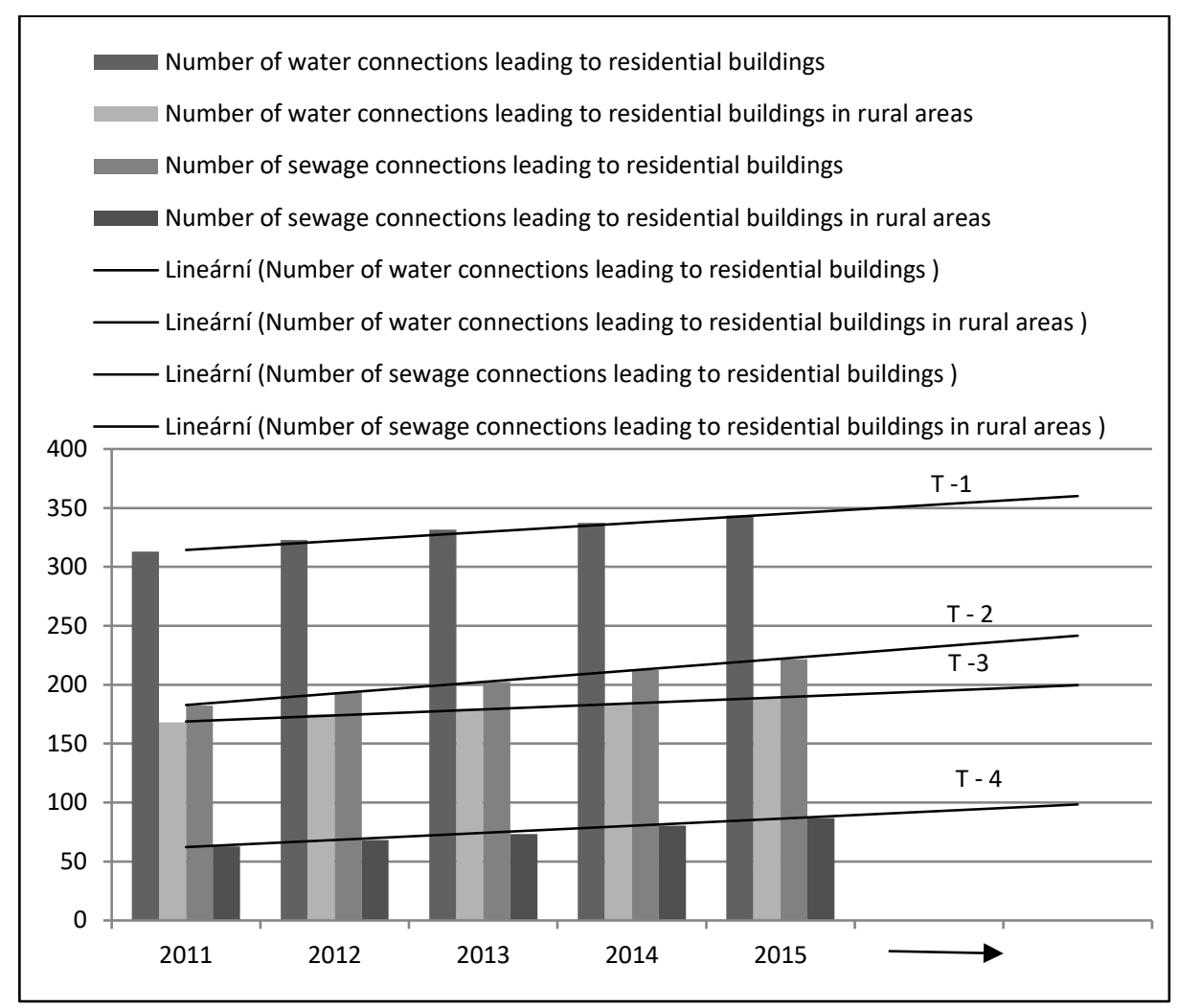

Fig. 5. Water and sewage connections leading to residential buildings in Dolnośląskie Voivodeship and in rural areas of Dolnośląskie Voivodeship in the years 2011-2015 and forecasted linear trend lines (number of connections in thousand.) [7].

lower in the rural areas of Dolnośląskie voivodeship (1 to 2.7), in year 2015 this relation was already more favorable, both in the Dolnośląskie voivodeship (1 to 1.5) as well as in the rural areas of Dolnośląskie voivodeship (1 to 2.2) (see Fig. 5). In this drawing the predicted trend lines are also shown (predicted linear trend line of number of water connections leading to residential buildings (T-1), predicted linear trend line of number of sewage connections leading to residential buildings (T-2), predicted linear trend line of number of water connections leading to residential buildings in the rural areas of Dolnośląskie Voivodeship (T-3) and predicted linear 
trend line of number of sewage connections leading to residential buildings in the rural areas of Dolnośląskie Voivodeship (T-4)) (see Fig. 5).

According to data analysis, in year 2015, compared to year 2011, the population in the Dolnośląskie Voivodeship decreased, which drained the sewage system with a sewage network (a decrease of just over 10\%, to 1812.8 thousand persons). In the same period, the number of such persons increased in the rural areas of Dolnośląskie Voivodeship (almost by half, to 386.7 thousand persons). In earlier sections of this study, the number of inhabitants of the Dolnośląskie voivodeship was decreasing in the years 2011-2015 (by 12370 people), which was influenced by the decrease in the number of inhabitants of the Dolnośląskie Voivodeship towns. The reported phenomenon of the decrease in the overall population of the analyzed voivodeship did not, however, affect the indicators informing about the number of population using the water supply network. In the years 2011-2015, the total number of population

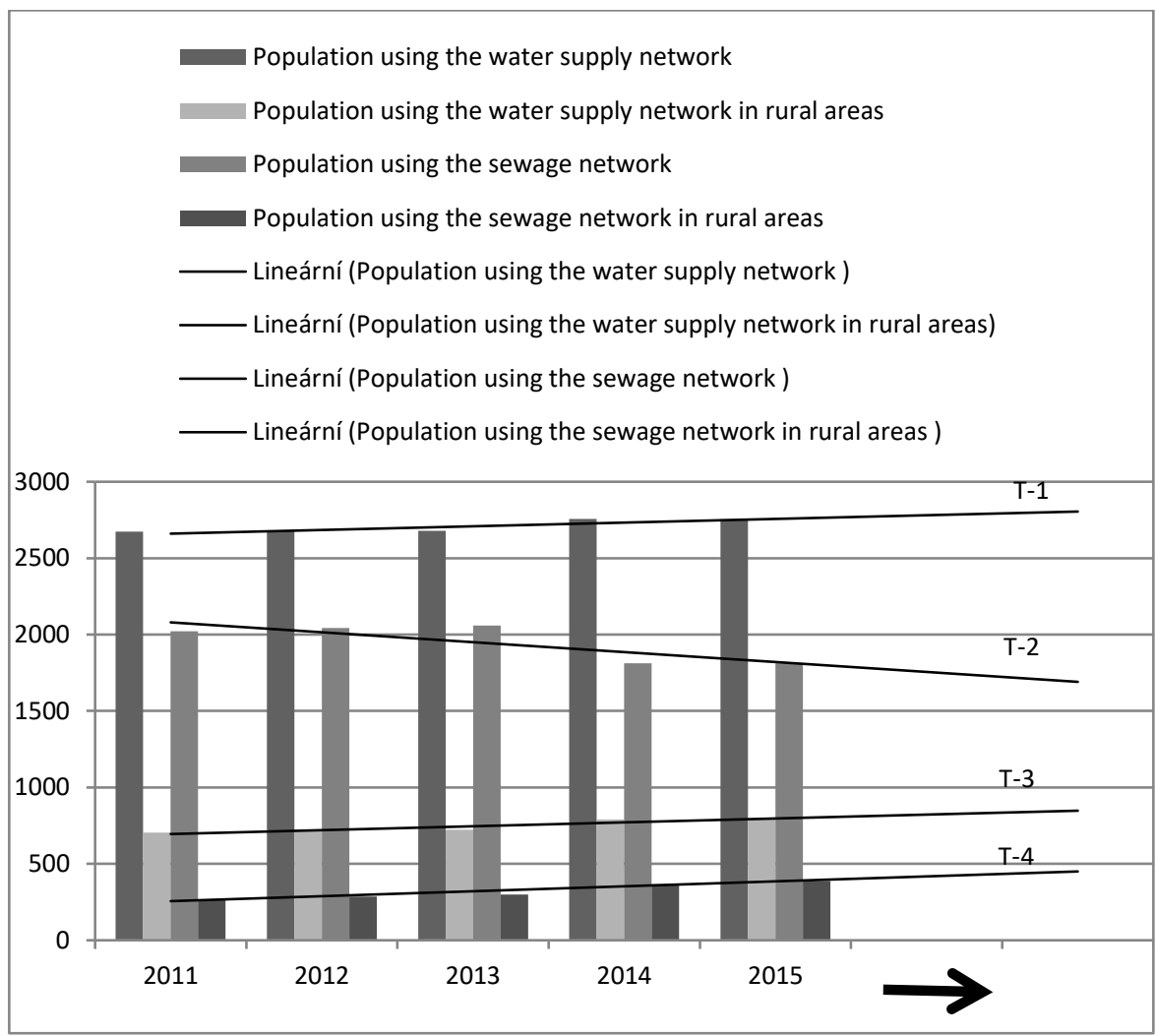

Fig. 6. Population using the water and sewage network in the Dolnośląskie Voivodeship and in rural areas of Dolnośląskie Voivodeship in the years 2011-2015 and forecasted linear trend lines (in thousand) [7].

using the water supply system in the Dolnośląskie Voivodeship increased (by $3 \%$, to 2754.9 thousand persons) as well as the number of inhabitants living in rural areas 
of the Dolnośląskie Voivodeship (increase by almost $13 \%$, to 794 . 9 thousand people). In this drawing the predicted trend lines are also shown (predicted linear trend line of population using the water supply network in Dolnośląskie Voivodeship (T-1), predicted linear trend line of population using the sewage network in Dolnośląskie Voivodeship (T-2); predicted linear trend line of population using the water supply network in rural areas of Dolnośląskie Voivodeship (T-3) and predicted linear trend line of population using the sewage network in rural areas of Dolnośląskie Voivodeship (T-4)) (see Fig. 6).

The change was accompanied by an increase in the population of the Dolnoślaskie Voivodeship, which uses wastewater treatment plants, to 2315.2 thousand people in year 2015 (an increase of just over 3\% compared to year 2011) (see Fig. 7). In this drawing the predicted trend lines are also shown (predicted linear trend line of population using the water supply network (T-1), predicted linear trend line of population using the sewage network (T-2) and predicted linear trend line of population using wastewater treatment plants (T-3) (see Fig. 7).

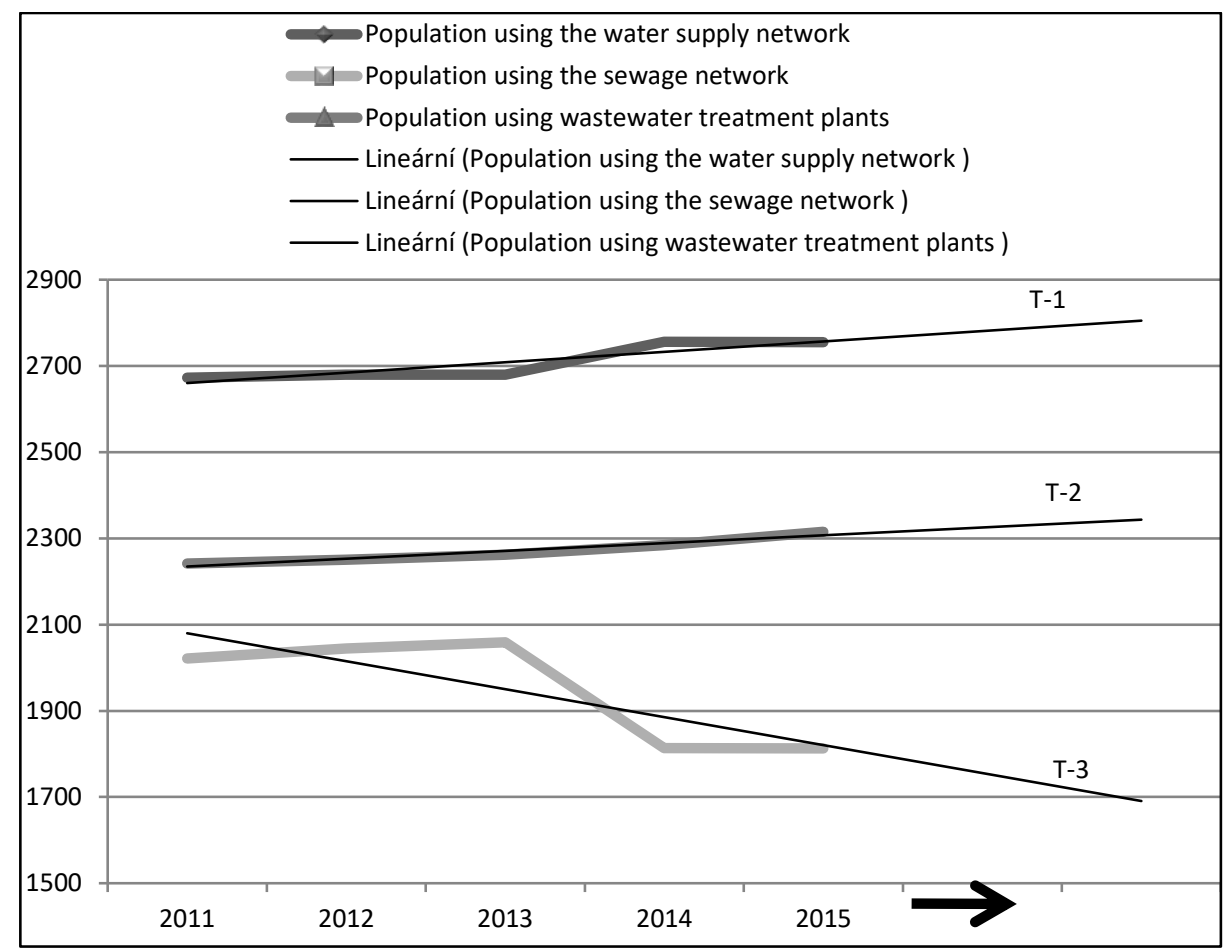

Fig. 7. Population using water supply, sewerage and sewage treatment plants in the Dolnośląskie Voivodeship in 2011-2015 and forecasted linear trend lines (in thousand) [7].

Sewage management was significantly weaker than the water management in the Dolnośląskie Voivodeship. Nevertheless, there are clear regional differences. The 
smallest (and degraded) are the communes of the southern part of this voivodeship, especially mountain communities. The average degree of sewerage (and drainage) of towns in Dolnośląskie Voivodeship is relatively high [8].

\section{Conclusion}

In the analysed period (2011-2015), in the Dolnośląskie Voivodeship, expenditure on fixed assets for environmental protection remained on the upward trend track. This should be assessed as a very beneficial phenomenon, due to the still unsatisfactory socio-economic and ecological needs for equipping this region with adequate technical infrastructure.

The main directions of financial support in the examined area were the sewage management and the protection of waters. These directions was under-invested in the earlier period, especially in the rural areas of Dolnośląskie Voivodeship. In many regions of the voivodeship these systems were dominated by water supply systems without sewage systems. In addition, sewerage networks were often deprived of sewage treatment plants. After Poland's accession to the European Union, it was necessary to solve these problems (the existing Water Framework Directive), following the earlier harmonization of certain legal acts. The saturation of areas in water and sewage infrastructure and the treatment of wastewater has a significant impact on improving the quality of life of their inhabitants and increasingly determines the investment attractiveness of the regions concerned. At the same time it promotes the protection and improvement of the environment, health, preservation of cultural identity and development of territorial cohesion.

The increase in outlays on water and sewage management in the Dolnośląskie Voivodeship in the analysed period has been positively correlated with the increase in the length of the water and sewerage networks, the increase in the number of water and sewage connections leading to residential buildings and the increase in the number of people using the water supply and sewage treatment plants.

In the case of the indicator informing about the population of this voivodeship using the sewerage network, a downward trend has emerged. An in-depth analysis revealed the outlook for the downward trend forecast only for the urban areas of Dolnośląskie Voivodeship. On the other hand, in the rural areas of the voivodeship, the number of people using the sewerage network increased and it is expected that it will continue to grow (forecast upward trend). This phenomenon is linked to the observed increase in population in rural areas of the Dolnośląskie Voivodeship, at the decrease of the population in the urban areas of the voivodeship.

Air and climate protection has become increasingly important in the financing structure. This is correlated with accepted European priorities, especially for Central and Eastern Europe. A growing problem is the emission of gases and particulates from coal-fired households and the emission of gases and dusts caused by the intensive development of motor vehicles (low emissions).

In industrialized and urbanized areas, the Dolnośląskie Voivodeship is also experiencing a high level of traffic noise. Efforts are aimed at its reduction. It were 
reflected in expenditures on fixed assets for environmental protection in the analyzed voivodeship.

Expenditures for environmental protection in the Dolnośląskie Voivodeship in the analyzed period came from diversified domestic and foreign sources. Investments of own investors (mainly municipalities), large ecological funds and funds from abroad were the leading factor in the development of the water and sewage network.

Further improvements in fixed assets for environmental protection in the Dolnośląskie Voivodeship are to be implemented in the framework of the Infrastructure and Environment Operational Program 2014-2020, the European Regional Development Fund, the Norwegian Financial Mechanism and the European Economic Area Financial Mechanism and the LIFE + Financial Instrument.

\section{References}

1. Bartniczak, B., Ptak, M.: Finanse ochrony środowiska. Wybrane problemy. Wyd. Uniwersytetu Ekonomicznego we Wrocławiu, Wrocław (2009).

2. Becla, A., Czaja, S.: Prawo środowiskowe dla ekonomistów. Wyd. Akademii Ekonomicznej we Wrocławiu, Wrocław (2007).

3. Boć, J., Nowacki, K., Samborska-Boć, E.: Ochrona środowiska. Wyd. Kolonia Limited, Wrocław (2004).

4. Nowak, K.: Prawo środowiskowe dla ekonomistów. Wyd. Akademii Ekonomicznej we Wrocławiu, Wrocław (2007).

5. Poskrobko, B, Poskrobko, T.: Zarządzanie środowiskiem w Polsce. Polskie Wydawnictwo Naukowe, Warszawa (2012).

6. Ochrona środowiska archiwum. https://stat.gov.pl/obszary-tematyczne/srodowiskoenergia/srodowisko/ochrona-srodowiska-2016,1,17.html, last accessed 2017/09/26.

7. Województwo Dolnoślaskie. Regionalny Program Operacyjny Województwa Dolnośląskiego 2014-2020. https://zitwrof.pl/wpcontent/uploads/2016/03/RPO_WD_2014_2020.pdf, last accessed 2017/10/03.

8. Rocznik Statystyczny Województwa Dolnośląskiego archiwum. http://wroclaw.stat.gov.pl/publikacje-i-foldery/roczniki-statystyczne/rocznik-statystycznywojewodztwa-dolnoslaskiego-2016,2,19.html, last accessed 2017/09/26. 